\title{
Compensatory function of the remaining testis is dissociated in boys and adolescents with monorchidism
}

\author{
Romina P Grinspon 1', Carolina Habib ${ }^{1}$, Patricia Bedecarrás ${ }^{1}$, Silvia Gottlieb ${ }^{1}$ and \\ Rodolfo A Rey ${ }^{1,2}$ \\ ${ }^{1}$ Centro de Investigaciones Endocrinológicas ‘Dr. César Bergadá' (CEDIE), CONICET-FEl, División de Endocrinología, \\ Hospital de Niños Ricardo Gutiérrez, Gallo 1330, C1425EFD Buenos Aires, Argentina and ${ }^{2}$ Departamento de \\ Histología, Biología Celular, Embriología y Genética, Facultad de Medicina, Universidad de Buenos Aires, \\ Buenos Aires, Argentina
}

\author{
Correspondence \\ should be addressed \\ to R A Rey \\ Email \\ rodolforey@cedie.org.ar
}

\begin{abstract}
Objective: Compensatory hypertrophy has been classically described in patients with monorchidism. However, it remains unclear whether there is a functional compensatory activity of the different cell populations. Our aim was to assess the functional capacity of the solitary testis in monorchid males from infancy through puberty in order to determine whether the remaining gonad is capable of compensating the functional activity of Sertoli and Leydig cells of the absent gonad. Design: In a retrospective, cross-sectional, analytical study performed at a tertiary paediatric public hospital, we included 89 boys with monorchidism and 358 healthy controls, aged 6 months-18 years. Testicular volume and circulating levels of reproductive hormones were compared between patients with monorchidism and normal boys. Serum anti-Müllerian hormone $(\mathrm{AMH})$ and FSH were used as biomarkers of the functional mass of prepubertal Sertoli cells, whereas serum testosterone and LH were used as biomarkers of Leydig cells.

Results: In the vast majority of the cases, the testicular volume of monorchid boys was smaller than the sum of the volume of both testes of healthy controls. Serum AMH was lower and FSH was higher in patients with monorchidism than in controls aged $<3$ and $>13$ years. Serum testosterone and LH did not differ significantly between patients and controls.

Conclusion: In boys and adolescents with monorchidism, there is a dissociated capacity of the remaining testis to compensate for the absence of the other gonad: while Leydig cell function is largely compensated, Sertoli cell proliferation and function was lower than in controls.
\end{abstract}

\section{Introduction}

Compensatory hypertrophy of a paired organ is a frequent observation when one of the organs is hypotrophic or absent. Compensatory testicular hypertrophy was first described by Laron \& Zilka (1) in patients with unilateral cryptorchidism, and is typically described in males with monorchidism. Size enlargement of the scrotal gonad has even been proposed to be predictive of the absence of the contralateral testis $(2,3,4)$. Yet, hypertrophy of the persistent organ does not guarantee full compensation of paired organ function.
Monorchidism can be congenital (5) or acquired as a consequence of different insults such as infection, testicular torsion and orchiectomy due to testicular tumours or testicular atrophy after orchiopexy. Its prevalence rate is $0.02 \%$ in newborn boys (6) and $1.7-4 \%$ in cryptorchid boys $(6,7)$. The mechanism by which the compensatory hypertrophy occurs is not known. Some studies suggest that compensatory hypertrophy depends on factors such as age of onset of monorchidim and functional state of the present testes (2).

Published by Bioscientifica Ltd. 
The male gonad has two distinctive functional compartments, which evolve differently through postnatal development: the seminiferous tubules, containing Sertoli and germ cells, and the interstitial tissue, where lie the Leydig cells (8). Sertoli cells represent the major proportion of testicular volume before puberty (9). During the active period of the pituitary-gonadal axis taking place in the first 3-6 months of postnatal life $(10,11,12)$, follicle-stimulating hormone (FSH) provokes Sertoli cell proliferation and boosts the secretion of antiMüllerian hormone (AMH) (13) and of inhibin B (14), whereas luteinizing hormone (LH) induces Leydig cell androgen production. Afterwards, pituitary gonadotropin levels decline and persist low during childhood. Leydig cells dedifferentiate and androgen production drops to undetectable amounts, and germ cell activity is arrested at the pre-meiotic stage. Although there is a waning in Sertoli cell proliferation, they remain functionally active, as reflected by their production of AMH (9) and inhibin B (15). At the age of pubertal onset, the increase in gonadotropins induces testosterone production, which results in the maturation of the seminiferous tubule populations: Sertoli cell AMH secretion declines at the time germ cells undergo the full spermatogenic process leading to the overt increase in testicular volume and to sperm production.

The reproductive aptitude of monorchid males has been reported in adults $(16,17)$, but the functional capacity of the solitary testis has received little attention in the paediatric population, with its assessment having relied mainly on the measurement of indirect markers of testicular function, like serum gonadotropins $(7,18)$, which lacks adequate sensitivity (19). Therefore, it remains unclear whether scrotal testis hypertrophy can functionally compensate the activity of the different cell populations of the missing gonad $(6,7)$. The aim of this study was to assess the functional capacity of the solitary testis in monorchid males from infancy through puberty in order to determine whether the remaining gonad is capable of compensating the functional activity of Sertoli and Leydig cells of the absent gonad. Secondarily, we analysed whether AMH levels are associated with the degree of compensatory hypertrophy in prepubertal boys with monorchidism. We studied a large cohort of 89 patients with monorchidism and compared them with 358 healthy controls in terms of circulating levels of reproductive hormones. Serum AMH and testosterone were used as direct biomarkers of Sertoli (15) and Leydig cell function respectively, whereas FSH and LH were used as indirect biomarkers. Hitherto, there is no effective method to certify the existence or the absence of nonpalpable gonads. Both ultrasound and MRI have low sensitivity in the identification of abdominal testes (20, 21, 22). Laparoscopy, the most commonly used procedure, may also have false negative results (23). In the quest for a non-invasive test that could circumvent surgery, we also analysed whether AMH levels could be useful to certify the absence of the non-palpable testis.

\section{Subjects and methods}

\section{Study design}

This study followed a retrospective, cross-sectional and analytical design, and was performed at the Division of Endocrinology of the Ricardo Gutiérrez Children's Hospital, a tertiary paediatric public hospital in Buenos Aires, Argentina.

A careful review of history charts was performed by the same paediatric endocrinologist. Surgical and clinical characteristics, including testicular volume measured by comparison with Prader's orchidometer (24), pubic hair and genital development according to Marshall \& Tanner (25), and hormonal values were extracted from the history chart.

\section{Patients}

Patients with monorchidism $~$ All clinical charts of subjects evaluated at the Division of Endocrinology of the Ricardo Gutiérrez Children's Hospital between 1997 and 2012, and recorded in our database with the diagnosis of monorchidism, were reviewed. Monorchidism was defined by the absence of one testis, as verified by surgical exploration. Patients whose history chart was incomplete, and those with disorders of sex development, hypogonadotropic hypogonadism or genetic syndromes that can affect testicular function, were excluded.

Healthy controls $>$ Between January 2007 and December 2009, 358 apparently normal males with no history of endocrine or urologic disorders, aged 2 days-18 years, attending the Central Laboratory of the Ricardo Gutiérrez Children's Hospital, were recruited to establish reference values for serum LH, FSH, testosterone, and $\mathrm{AMH}$, as previously described (26).

\section{Outcome measures and definitions}

Circulating levels of reproductive hormones were compared between patients with monorchidism and 
normal boys. Serum AMH and FSH were respectively used as direct and indirect biomarkers of the functional mass of prepubertal Sertoli cells (15), whereas serum testosterone and LH were respectively used as direct and indirect biomarkers of Leydig cells.

In prepubertal patients, to determine whether AMH levels reflect the degree of compensatory hypertrophy in boys with monorchidism, we evaluated the correlation between serum AMH and testicular volume. This analysis was limited to boys $<9$ years old, because after the onset of puberty, testicular volume is inversely correlated with the levels of AMH due to the inhibitory effect of androgens on Sertoli cell $(13,27)$. Only the first AMH measurement available for each patient was included in the crosssectional analysis. To evaluate if AMH levels are useful to certify the absence of the non-palpable testis in prepubertal boys, we performed a receiver operating characteristic (ROC) curve analysis considering boys with monorchidism as cases and healthy boys as controls.

Pubertal onset was assumed only when testicular volume increase was accompanied by secondary sexual characteristics rather than by the sole occurrence of testicular volume $\geq 4 \mathrm{ml}$, since compensatory hypertrophy in prepubertal children may result in testicular volume beyond $4 \mathrm{ml}$. For the primary analysis, patients with monorchidism and controls were grouped by age intervals. A secondary analysis was performed according to Tanner stage.

To determine if the existence of compensatory hypertrophy depends on the age at which the monorchidism was established, we compared the existence and degree of compensatory hypertrophy between children with congenital and those with acquired monorchidism. Compensatory hypertrophy was defined by the existence of testicular volume $>2 \mathrm{ml}$ in prepubertal boys or $>25 \mathrm{ml}$ in pubertal boys (4).

The sample size was calculated for the main outcome measure, i.e. the comparison between AMH levels in patients with monorchidism and healthy control boys $<9$ years old. The estimated study size required to incorporate 55 boys in each group in order to detect a difference of at least 30\% in serum AMH levels between monorchid and control boys, with a power of $80 \%$ and an $\alpha$ error of $5 \%$.

\section{Hormone assay methods}

Anti-Müllerian hormone $>$ AMH was determined using an enzyme-linked immunoassay specific for human AMH (EIA AMH/MIS, Beckman Coulter Co., Marseilles, France), as previously validated by our group $(19,26)$. Intra- and inter-assay coefficients of variation $(\mathrm{CV})$ were 10.5 and 9.4\% for a serum AMH concentration of $700 \mathrm{pmol} / \mathrm{l}$, and 11.1 and $12.8 \%$ for a serum $\mathrm{AMH}$ concentration of $7 \mathrm{pmol} / \mathrm{l}$ respectively.

Gonadotropins $\bullet$ LH and FSH were determined using electrochemiluminescent immunoassays (ECLIA, Roche Diagnostics $\mathrm{GmbH}$ ) as described (19). Intra- and interassay CV were 1.1 and $1.8 \%$ for $\mathrm{LH}$ for a mean $\mathrm{LH}$ concentration of $2.8 \mathrm{IU} / \mathrm{l}$, and 1.4 and $1.5 \%$ for a mean $\mathrm{LH}$ concentration of $16.9 \mathrm{IU} / \mathrm{l}$ respectively. Intra- and interassay CV were 1.0 and $4.2 \%$ for FSH for a mean FSH concentration of $14.8 \mathrm{IU} / \mathrm{l}$, and 1.1 and $4.1 \%$ for a mean FSH concentration of $23.4 \mathrm{IU} / 1$ respectively. When serum LH or FSH levels were undetectable, the value of the limit of quantification (functional sensitivity) was attributed.

Testosterone - Testosterone was determined in serum using an ECLIA (Roche Diagnostics $\mathrm{GmbH}$ ) as described (19). Intra- and inter-assay CV were 2.4 and $2.6 \%$ for a mean testosterone concentration of $176 \mathrm{ng} / \mathrm{dl}$ $(6.10 \mathrm{nmol} / \mathrm{l})$, and 1.2 and $2.3 \%$ for a mean testosterone concentration of $455 \mathrm{ng} / \mathrm{dl}(15.78 \mathrm{nmol} / \mathrm{l})$ respectively.

\section{Statistical analysis}

Data distribution was assessed for normality using the Shapiro-Wilk test. Results are expressed as median and interquartile range (IQR). Because non-Gaussian distribution was found in most cases, non-parametric tests were used for comparisons. Mann-Whitney $U$ test was used to compare serum hormone levels between two independent groups. Fisher's exact test was used to compare categorical variables. The correlation coefficient between testicular volume and serum AMH in patients with monorchidism was calculated using the non-parametric Spearman's test. The level of significance was set at $P<0.05$. All statistical analyses were performed using GraphPad Prism version 5.01 for Windows (GraphPad Software, San Diego, CA, USA).

\section{Ethical issues}

The study protocol was approved by the Institutional Review Board and Ethics Committee of the Ricardo Gutiérrez Children's Hospital. Because the study of patients with monorchidism was based on a retrospective clinical chart review with descriptive purposes and no anticipated effect on prognosis or therapeutic 
management of the patients whose charts were included, the need for a written informed consent was waived. For the control group, written informed consent was given by the participant's parents, and assent was given by the participants over 7 years of age.

\section{Results}

\section{Characteristics of the study population}

Out of the 119 eligible cases (Fig. 1), 89 patients with monorchidism aged 1.1-18.7 years were included in the analysis. Median age at first visit was 5.1 years (range 0.314.5 years). A total of 168 serum samples were assessed, since follow-up was available in 83 of the 89 patients, with a median follow-up of 7.3 years (range $0.4-17.3$ years). The prevalence of left monorchidism, i.e. absence of the right testis, was 48 cases (54\%) in our series. The occurrence of acquired monorchidism was ascertained in 44 patients

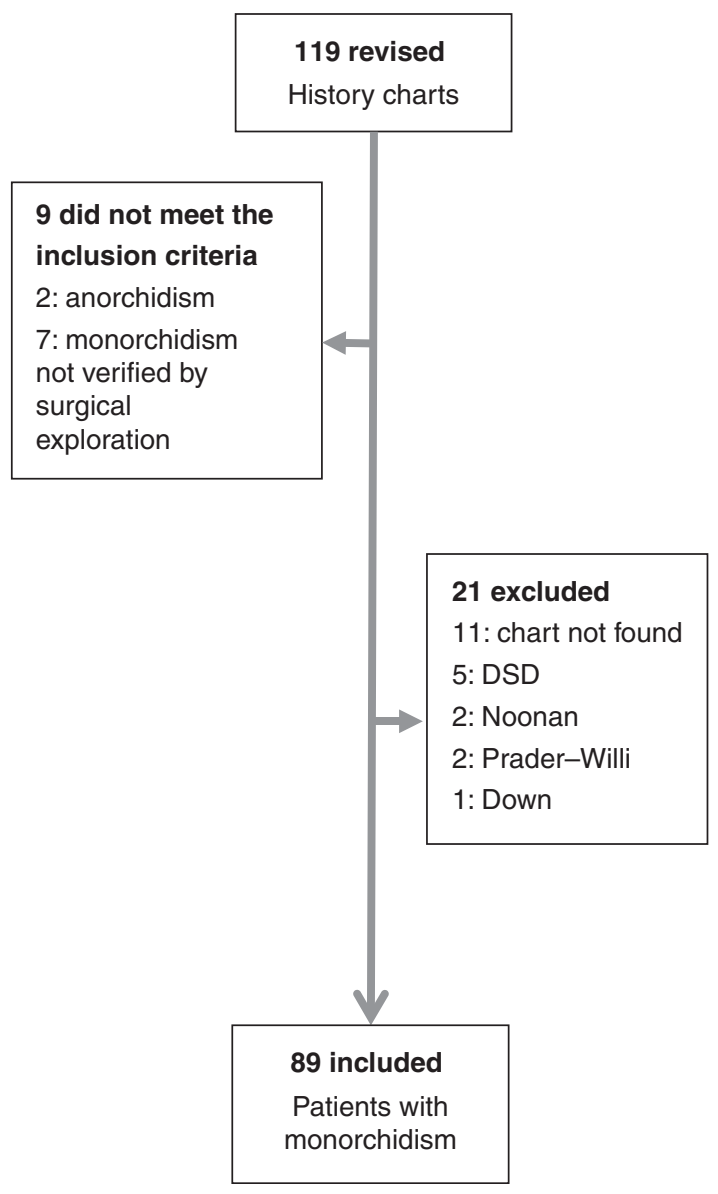

Figure 1

Flow diagram of enrolment of patients with monorchidism.
(49\%): orchiectomy due to testicular tumour in seven cases and to atrophic testis with testicular-epididymal dissociation in four, atrophy following orchiopexy in 20, testicular torsion in 11, mumps orchitis in one, and trauma in one. In the remaining 45 patients, only one testis was palpable at birth, and an acquired aetiology for monorchidism could not be evidenced; hence, congenital monorchidism was suspected.

\section{Monorchidism in boys $<9$ years old}

In prepubertal age ( $<9$ years old), $59.5 \%$ of boys with monorchidism presented moderate hypertrophy of the remaining gonad. The volume of the solitary testis of monorchid children was not significantly different from that of the largest testis of healthy controls aged 6 months-2.9 years, but it was bigger in monorchid boys than in controls aged 3-8.9 years. However, the volume of the testis of monorchid boys was smaller than the bi-testicular volume of controls in both subgroups (Table 1), indicating that testicular hypertrophy did not fully compensate the tissue mass of two gonads.

In concordance, median serum AMH was significantly lower in patients with monorchidism than in age-matched controls (Table 1). Testicular volume correlated significantly with AMH in boys $<9$ years (Fig. 2), showing that AMH levels reflect the degree of hypertrophy in prepubertal patients with monorchidism. AMH levels were below the normal range in four out of six cases in the monorchid boys aged $<3$ years and in 13 out of 39 cases in the 3-8.9 years old subgroup (Fig. 3). To test whether the absence of one testis during the postnatal activation period of the hypothalamic-pituitary-gonadal axis could elicit a greater compensatory response, we analysed separately patients with congenital monorchidism. In the 6 months -2.9 years group, boys with congenital monorchidism (median age: 1.5 years and IQR: 1.2-2.0 years) had a lower serum AMH (median: $324 \mathrm{pmol} / 1$ and IQR: 204-939 pmol/l) than healthy controls (median age: 1.9 years and IQR: 1.0-2.4) in whom AMH was 1067 (IQR: 807-1460) pmol/1 (two-tailed Mann-Whitney $U$ test 17.0; $P=0.008$ ). Similarly, in the $3.0-8.9$ years group, boys with congenital monorchidism (median age: 5.9 years and IQR: 4.2-7.4 years) had a lower AMH: 465 (IQR: 180-641) $\mathrm{pmol} / \mathrm{l}$ than controls (median age: 5.4 years and IQR: 4.3-7.0 years) 596 (IQR: 420-873) pmol/1 (two-tailed Mann-Whitney $U$ test $693.5, P=0.024$ ).

To rule out the possibility that AMH was lower in patients with monorchidism because the remaining testis was not normal, we analysed a subset of 13 monorchid 
Table 1 Testicular volume and reproductive axis hormone levels in 45 boys with monorchidism and in 147 healthy controls aged $<9$ years. Results are expressed as medians (interquartile range) and were compared using the Mann-Whitney $U$ test.

\begin{tabular}{|c|c|c|c|c|c|c|}
\hline & \multicolumn{3}{|c|}{6 months -2.9 years old } & \multicolumn{3}{|c|}{ 3-8.9 years old } \\
\hline & Monorchidism & Control & $P$ & Monorchidism & Control & $P$ \\
\hline Age & $1.3(1.1-1.7)$ & $1.9(1.0-2.4)$ & & $6.6(4.4-7.7)$ & $5.4(4.3-7.0)$ & \\
\hline \multirow[t]{2}{*}{ Testicular volume $(\mathrm{ml})^{\mathrm{a}}$} & $2(0.5-3)$ & $\mathrm{L}: 2(1-2)$ & 0.735 & $3(0.5-5)$ & $\mathrm{L}: 2(1-3)$ & $<0.001$ \\
\hline & & B: $4(2-4)$ & 0.004 & & B: $4(2-6)$ & $<0.001$ \\
\hline AMH (pmol/l) & $324(221-820)$ & 1067 (807-1460) & 0.0009 & $403(203-637)$ & $596(420-873)$ & 0.001 \\
\hline $\mathrm{FSH}(\mathrm{IU} / \mathrm{I})$ & $1.10(0.72-6.72)$ & $0.63(0.26-1.37)$ & 0.017 & $0.99(0.27-3.30)$ & $0.79(0.20-3.21)$ & 0.106 \\
\hline Testosterone (ng/dl) & $10(10-21)$ & $10(10-10)$ & NA & $10(10-66)$ & $10(10-10)$ & NA \\
\hline $\mathrm{LH}(\mathrm{IU} / \mathrm{I})$ & $0.07(0.10-0.63)$ & $0.10(0.10-0.43)$ & 0.580 & $0.10(0.05-0.28)$ & $0.10(0.10-0.19)$ & 0.519 \\
\hline
\end{tabular}

NA: statistical analysis was not applicable, since testosterone levels were below the lower limit of detection of the assay in the vast majority of boys with monorchidism and in healthy controls.

${ }^{a}$ Testicular volume reflects that of the only testis in boys with monorchidism and in healthy controls that of the largest testis ( $\mathrm{L}$ ) or that of the sum of both testes (B).

patients with no history compatible with damage of the remaining testis, i.e. monorchidism due to surgical removal of one testis following testicular torsion, traumatism or tumour (Fig. 3). Although the sample size was limited, serum AMH was low in nine of them (69.2\%), suggesting that one testis with no overt history of defect is unable to fully compensate Sertoli cell function.

In order to evaluate if AMH level was useful in prepubertal boys to certify the existence of only one gonad, we performed a ROC curve analysis, comparing monorchid boys as cases and healthy boys as controls. Area under the ROC curve was 0.772 (95\% CI 0.687 0.856), and the best cut-off value (AMH $400 \mathrm{pmol} / \mathrm{l}$ ) had very low sensitivity $(52.4 \%$; 95\% CI $36.4-68.0 \%)$ and insufficient specificity $(89.8 \%$; $95 \%$ CI $83.7-94.2 \%)$ to diagnose monorchidism.

Median serum FSH was moderately increased in boys with monorchidism below the age of 3 years, i.e. just after the postnatal activation of the pituitary-gonadal axis, but not during the rest of childhood. Testosterone and LH were within the normal range in patients with monorchidism $<9$ years old (Table 1 and Fig. 3 ).

\section{Monorchidism in boys older than 9 years old}

In patients with monorchidism aged 9 years or older, the volume of the present testis was $>25 \mathrm{ml}$ in $20 \%$ of the cases. From the age of 13 years onwards, i.e. when patients were in the most advanced stages of pubertal development, the size of the solitary testis of monorchid boys was significantly bigger than the largest testis of healthy controls, but it did not reach the normal bi-testicular volume (Table 2), indicating that testicular hypertrophy did not fully compensate the tissue mass of two gonads.
AMH levels were significantly lower, and FSH were significantly higher in patients with monorchidism (Table 2 and Fig. 3), indicating that the seminiferous tubule compartment of the solitary testis was unable to fully compensate the function of the absent gonad. Conversely, LH and testosterone showed no significant differences between patients with monorchidism and healthy controls, showing that the interstitial tissue of the solitary testis was capable of compensating the androgenic function.

\section{Discussion}

The results of this survey, which included 89 patients with monorchidism spanning infancy, childhood and puberty, indicate that there is a dissociated capacity of the remaining testis to fully compensate for the absence of

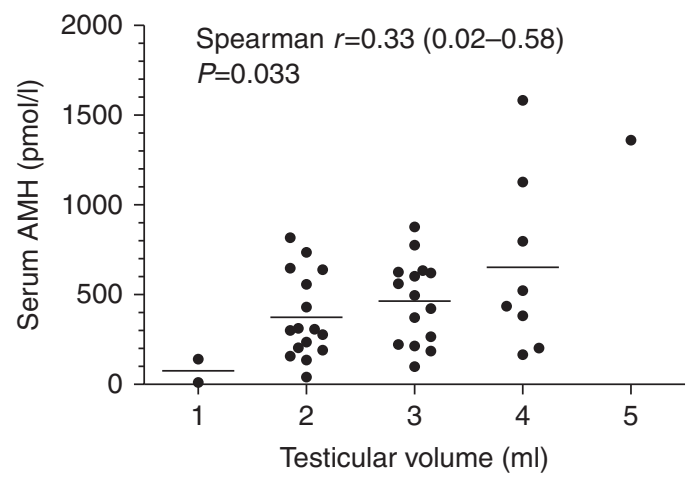

\section{Figure 2}

Correlation between serum anti-Müllerian hormone (AMH) levels and testicular volume in prepubertal boys with monorchidism. 

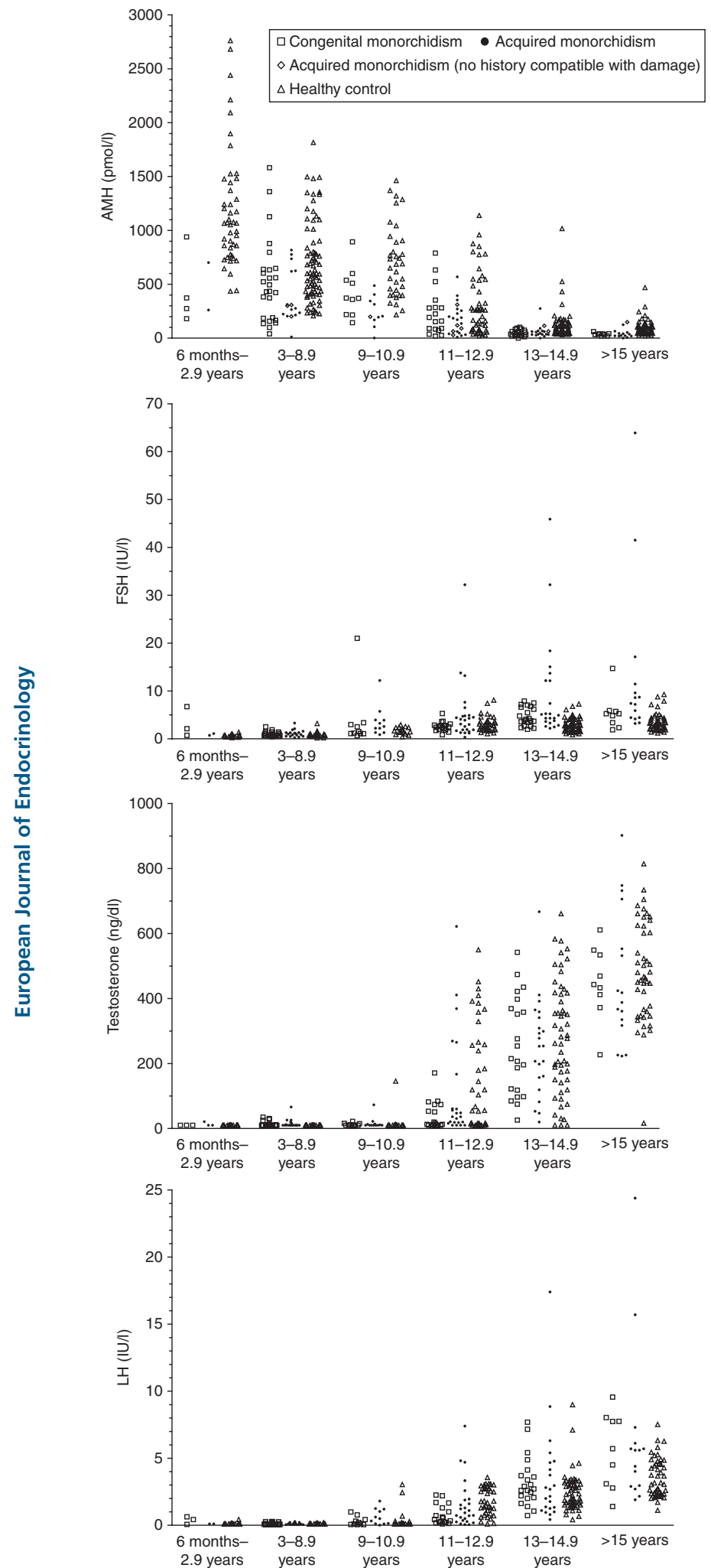

Figure 3

Serum reproductive hormone levels in boys with monorchidism and in healthy controls. the other gonad: while Leydig cell function is largely compensated, Sertoli cell proliferation and function is insufficient. Indeed, testosterone and LH levels were normal during pubertal development in the vast majority of patients with monorchidism, in line with previous results in a small series of 11 patients (28). Conversely, lower $\mathrm{AMH}$ and higher FSH in monorchid boys indicate that the remaining testis does not fully compensate the function of the absent one. Furthermore, the volume of the testis is primarily dependent on the mass of Sertoli cells in prepuberty; after puberty, testicular volume is determined by germ cell numbers, which is limited by the peak number of Sertoli cells reached at during infancy and childhood (29). In both prepubertal and pubertal patients with monorchidism of this study, although the volume of the testis was larger than the mean volume of the two gonads of healthy controls, it did not reach the double of a normal testis, thus indicating that the number of Sertoli cells of the remaining gonad was insufficient to fully compensate the absence of the second testis. This is in concordance with low inhibin B levels observed in a small series of boys (28) and with oligospermia reported in adult males (16) with monorchidism. For ethical reasons, semen analysis was not performed in our patients; therefore, we cannot guarantee that insufficient testicular volume compensation resulted in oligospermia or impaired fertility outcome.

In patients with unilateral cryptorchidism or monorchidism, testis hypertrophy and functional compensation by the scrotal gonad is believed to be dependent on three factors: the magnitude of functional reduction of the testicular parenchyma of the affected gonad, the age at injury and the status of the descended testis. Congenital monorchidism and acquired monorchidism may occur in patients in whom a primary testicular disorder affecting both testes could be suspected, for instance in the testicular regression syndrome $(6,7)$ and in patients with a history of unilateral or bilateral cryptorchidism $(1,17)$. In these cases, the remaining testis may be dysfunctional and, thus, inept for functional compensatory hypertrophy. The lower AMH levels observed in our patients with monorchidism are most probably not due to a primary defect of the present testis, at least in the subset of cases in whom a history compatible with primary gonadal dysfunction could be ruled out.

The precise mechanism underlying the enlargement of the remaining testis in monorchid patients is not fully understood. The effect of increased FSH levels is suspected to be at least partially responsible for Sertoli cell hyperplasia. Compensatory hypertrophy would then be 
more likely in patients with congenital monorchidism in whom the early postnatal activation of the hypothalamicgonadotrope axis would be exaggerated (19). In the present study, we could not demonstrate any compensatory function in patients with congenital monorchidism.

The major strength of this work is that we analysed a large series of patients with certified monorchidism during childhood by assessing serum AMH, a validated marker of testicular function with no need for stimulation tests. Indeed, while the gonadotrophs and Leydig cells are functionally quiescent in boys between infancy and puberty, Sertoli cells remain active and secrete huge amounts of $\mathrm{AMH}$. Therefore, serum AMH is a widely accepted biomarker of testicular activity during childhood $(30,31,32,33,34,35,36)$. Furthermore, serum AMH has been postulated as a surrogate marker for the mass of functional Sertoli cells in patients with gonadal dysgenesis (37), hypogonadotropic hypogonadism $(14,38)$ and Sertoli cell hyperplasia $(39,40)$. In the present work, the significant correlation between testicular volume and $\mathrm{AMH}$ suggested that AMH levels reflect the degree of compensatory hypertrophy in prepubertal patients with monorchidism.

Owing to its retrospective design, our study has some limitations: testis volume values obtained from the history charts had been measured by the patient's paediatric endocrinologist and not by only one observer, which may have resulted in less precise results owing to greater CV than those obtained in a prospective study with only one or two observers. Also, testicular volume was obtained by comparison with Prader's orchidometer rather than by ultrasound measurements, which gives more accurate results. Yet, even if less accurate, measurements by the Prader's orchidometer show a strong correlation with ultrasound measurements (41). Another limitation of this study is that comparisons of reproductive hormone levels between patients and controls $>9$ years old were made according to age and not Tanner stage. The reason is that testicular volume is one of the most important features considered to distinguish between Tanner stages G2 and G3 (25), and testicular hypertrophy expected to occur in patients with monorchidism precluded the use of gonadal volume to assess pubertal maturation. Pubertal development stages are extremely variable between individuals, mainly in boys aged 11-13 years. The large interindividual variations could explain the lack of significant differences in serum AMH between monorchid patients and healthy controls only in this age group.

It should be noted that the differences observed in the median levels of the markers of Sertoli cell functional 
mass, i.e. $\mathrm{AMH}$ and $\mathrm{FSH}$, could be explained by the existence of a subset of patients with clearly abnormal values, while the remaining cases have normal levels. This suggests that two populations of patients with monorchidism may exist, including one with normal hormone levels who subsequently may prove to have normal fertility and the other with elevated FSH levels who may attain a subfertile state later in life.

Because the normal range of serum $\mathrm{AMH}$ is relatively large, it did not prove useful in our study to certify the lack of a second gonad, e.g. in abdominal position and in our study population. We are aware that a limitation of our study is that in the ROC curve analysis, we compared serum AMH of monorchid patients with that of healthy controls rather than with unilateral cryptorchid patients. However, the fact that serum AMH was unable to distinguish patients with monorchidism from healthy boys indicates that it would be less efficient to distinguish between patients with monorchidism and those with unilateral cryptorchidism.

In summary, patients with monorchidism show a dissociated capacity of compensation of testicular function: the interstitial compartment is capable to respond to LH increase with an adequate testosterone production, thus avoiding hypoandrogenism, whereas Sertoli cells seem unable to fully compensate for the absence of the other gonad, probably resulting in lower total cell numbers when compared to that of two testes and leading to a lower total testicular mass, a decreased $\mathrm{AMH}$ production and high circulating $\mathrm{FSH}$. Whether this may predict infertility needs to be addressed by studying patients with a sufficiently long follow-up until adulthood.

\section{Declaration of interest}

R P Grinspon, P Bedecarrás, and R A Rey have received honoraria from Consejo Nacional de Investigaciones Científicas y Técnicas (CONICET) (Argentina) for technology services using the AMH ELISA. C Habib and S Gottlieb have nothing to disclose.

\section{Funding}

This work was partially financed by grants PICT-2012-0441 of the Agencia Nacional de Promoción Científica, Argentina and PIP-11220120100279 of the CONICET, Argentina.

\section{Author contribution statement}

R P Grinspon, C Habib, and S Gottlieb reviewed the history charts of patients with monorchidism. R P Grinspon, S Gottlieb, and R A Rey recruited and performed the clinical assessment of healthy controls. P Bedecarrás managed the database and validated the $A M H$ assay. $R$ P Grinspon, C Habib, and R A Rey performed the analyses of the results. R P Grinspon and R A Rey wrote the manuscript. All authors approved the final version.

\section{Acknowledgements}

We are grateful to all the staff of the División de Endocrinología of the Hospital de Niños Ricardo Gutiérrez who cared for the patients and gave us access to clinical and laboratory data.

\section{References}

1 Laron Z \& Zilka E. Compensatory hypertrophy of testicle in unilateral cryptorchidism. Journal of Clinical Endocrinology and Metabolism 196929 1409-1413. (doi:10.1210/jcem-29-11-1409)

2 Koff SA. Does compensatory testicular enlargement predict monorchism? Journal of Urology 1991146 632-633.

3 Hurwitz RS \& Kaptein JS. How well does contralateral testis hypertrophy predict the absence of the nonpalpable testis? Journal of Urology 2001 165 588-592. (doi:10.1097/00005392-200102000-00077)

4 Shibata Y, Kojima Y, Mizuno K, Nakane A, Kato T, Kamisawa H, Kohri K $\&$ Hayashi Y. Optimal cutoff value of contralateral testicular size for prediction of absent testis in Japanese boys with nonpalpable testis. Urology 201076 78-81. (doi:10.1016/j.urology.2010.02.043)

5 Smith NM, Byard RW \& Bourne AJ. Testicular regression syndrome a pathological study of 77 cases. Histopathology 199119 269-272. (doi:10.1111/j.1365-2559.1991.tb00033.x)

6 Lamesch AJ. Monorchidism or unilateral anorchidism. Langenbecks Archiv für Chirurgie 1994379 105-108.

7 Kogan SJ, Gill B, Bennett B, Smey P, Reda EF \& Levitt SB. Human monorchism: a clinicopathological study of unilateral absent testes in 65 boys. Journal of Urology 1986135 758-761.

8 Rey RA, Grinspon RP, Gottlieb S, Pasqualini T, Knoblovits P, Aszpis S, Pacenza N, Stewart Usher J, Bergadá I \& Campo SM. Male hypogonadism: an extended classification based on a developmental, endocrine physiology-based approach. Andrology 20131 3-16. (doi:10.1111/j. 2047-2927.2012.00008.x)

9 Grinspon RP \& Rey RA. Anti-Müllerian hormone and Sertoli cell function in paediatric male hypogonadism. Hormone Research in Paediatrics 201073 81-92. (doi:10.1159/000277140)

10 Forest MG, Sizonenko PC, Cathiard AM \& Bertrand J. Hypophysogonadal function in humans during the first year of life. 1. Evidence for testicular activity in early infancy. Journal of Clinical Investigation 1974 53 819-828. (doi:10.1172/JCI107621)

11 Kuiri-Hänninen T, Sankilampi U \& Dunkel L. Activation of the hypothalamic-pituitary-gonadal axis in infancy, minipuberty. Hormone Research in Paediatrics 201482 73-80.

12 Rey RA. Mini-puberty and true puberty: differences in testicular function. Annales d'Endocrinologie 201475 58-63. (doi:10.1016/j.ando. 2014.03.001)

13 Lasala C, Carré-Eusèbe D, Picard JY \& Rey R. Subcellular and molecular mechanisms regulating anti-Müllerian hormone gene expression in mammalian and nonmammalian species. DNA and Cell Biology 200423 572-585. (doi:10.1089/dna.2004.23.572)

14 Bougnères $\mathrm{P}$, François M, Pantalone L, Rodrigue D, Bouvattier C, Demesteere E, Roger D \& Lahlou N. Effects of an early postnatal treatment of hypogonadotropic hypogonadism with a continuous subcutaneous infusion of recombinant follicle-stimulating hormone and luteinizing hormone. Journal of Clinical Endocrinology and Metabolism 200893 2202-2205

15 Grinspon RP, Loreti N, Braslavsky D, Bedecarrás P, Ambao V, Gottlieb S Bergadá I, Campo SM \& Rey RA. Sertoli cell markers in the diagnosis of 
paediatric male hypogonadism. Journal of Pediatric Endocrinology \& Metabolism 201225 3-11. (doi:10.1515/jpem-2011-0453)

16 Woodhead DM, Pohl DR \& Johnson DE. Fertility of patients with solitary testes. Journal of Urology 1973109 66-67.

17 Lee PA \& Coughlin MT. The single testis: paternity after presentation as unilateral cryptorchidism. Journal of Urology 2002168 1680-1683. (doi:10.1016/S0022-5347(05)64387-X)

18 Palmer LS, Gill B \& Kogan SJ. Endocrine analysis of childhood monorchism. Journal of Urology 1997158 594-596. (doi:10.1016/ S0022-5347(01)64563-4)

19 Grinspon RP, Ropelato MG, Bedecarrás P, Loreti N, Ballerini MG, Gottlieb S, Campo SM \& Rey RA. Gonadotrophin secretion pattern in anorchid boys from birth to pubertal age: pathophysiological aspects and diagnostic usefulness. Clinical Endocrinology 201276 698-705. (doi:10.1111/j.1365-2265.2011.04297.x)

20 Maghnie M, Vanzulli A, Paesano P, Bragheri R, Palladini G, Preti P, Del Maschio A \& Severi F. The accuracy of magnetic resonance imaging and ultrasonography compared with surgical findings in the localization of the undescended testis. Archives of Pediatrics \& Adolescent Medicine 1994148 699-703. (doi:10.1001/archpedi.1994. 02170070037006)

21 Elder JS. Ultrasonography is unnecessary in evaluating boys with a nonpalpable testis. Pediatrics 2002110 748-751. (doi:10.1542/ peds.110.4.748)

22 Krishnaswami S, Fonnesbeck C, Penson D \& McPheeters ML. Magnetic resonance imaging for locating nonpalpable undescended testicles: a meta-analysis. Pediatrics 2013131 e1908-e1916. (doi:10.1542/ 7peds.2013-0073)

23 McEachern R, Houle AM, Garel L \& Van Vliet G. Lost and found testes: the importance of the hCG stimulation test and other testicular markers to confirm a surgical declaration of anorchia. Hormone Research 200462 124-128. (doi:10.1159/000080018)

24 Zachmann M, Prader A, Kind HP, Hafliger H \& Budliger H. Testicular volume during adolescence. Cross-sectional and longitudinal studies. Helvetica Paediatrica Acta 197429 61-72.

25 Marshall WA \& Tanner JM. Variations in the pattern of pubertal changes in boys. Archives of Disease in Childhood 197045 13-23. (doi:10.1136/adc.45.239.13)

26 Grinspon RP, Bedecarrás P, Ballerini MG, Iñíguez G, Rocha A, Mantovani Rodrigues Resende EA, Brito VN, Milani C, Figueroa Gacitua V, Chiesa A et al. Early onset of primary hypogonadism revealed by serum anti-Müllerian hormone determination during infancy and childhood in trisomy 21. International Journal of Andrology 201134 e487-e498. (doi:10.1136/adc.45.239.13)

27 Rey R. Endocrine, paracrine and cellular regulation of postnatal antiMüllerian hormone secretion by Sertoli cells. Trends in Endocrinology and Metabolism 19989 271-276. (doi:10.1016/S1043-2760(98)00069-1)

28 Gaudino R, Cavarzere P, Camilot M, Teofoli F, Zampieri N \& Tato L. Prepubertal serum inhibin B in cryptorchid infants and in monorchid boys with compensatory testicular hypertrophy. Fertility and Sterility 200890 2217-2221. (doi:10.1016/j.fertnstert.2007.10.017)

29 Rey R. Regulation of spermatogenesis. Endocrine Development 20035 $38-55$.
30 Lee MM, Donahoe PK, Silverman BL, Hasegawa T, Hasegawa Y, Gustafson ML, Chang YC \& MacLaughlin DT. Measurements of serum Müllerian inhibiting substance in the evaluation of children with nonpalpable gonads. New England Journal of Medicine 1997336 1480-1486. (doi:10.1056/NEJM199705223362102)

31 Lee MM, Misra M, Donahoe PK \& MacLaughlin DT. MIS/AMH in the assessment of cryptorchidism and intersex conditions. Molecular and Cellular Endocrinology 2003211 91-98. (doi:10.1016/ j.mce.2003.09.014)

32 Lahlou N, Fennoy I, Carel JC \& Roger M. Inhibin B and anti-Müllerian hormone, but not testosterone levels, are normal in infants with nonmosaic Klinefelter Syndrome. Journal of Clinical Endocrinology and Metabolism 200489 1864-1868. (doi:10.1210/jc.2003-031624)

33 Cuny A, Trivin C, Brailly-Tabard S, Adan L, Zerah M, Sainte-Rose C, Alapetite C, Brugieres L, Habrand JL, Doz F et al. Inhibin B and antiMüllerian hormone as markers of gonadal function after treatment for medulloblastoma or posterior fossa ependymoma during childhood. Journal of Pediatrics 2011158 1016-1022.e1. (doi:10.1016/ j.jpeds.2010.11.019)

34 Aksglaede L, Christiansen P, Sorensen K, Boas M, Linneberg A, Main KM, Andersson AM, Skakkebæk NE \& Juul A. Serum concentrations of anti-Müllerian hormone (AMH) in 95 patients with Klinefelter syndrome with or without cryptorchidism. Acta Paediatrica 2011100 839-845. (doi:10.1111/j.1651-2227.2011.02148.x)

35 Valeri C, Schteingart HF \& Rey RA. The prepubertal testis: biomarkers and functions. Current Opinion in Endocrinology, Diabetes, and Obesity 201320 224-233. (doi:10.1097/MED.0b013e328360be2c)

36 Josso N, Rey RA \& Picard JY. Anti-Müllerian hormone: a valuable addition to the toolbox of the pediatric endocrinologist. International Journal of Endocrinology 20132013 674105. (doi:10.1155/2013/674105)

37 Rey R, Al-Attar L, Louis F, Jaubert F, Barbet P, Nihoul-Fékété C, Chaussain JL \& Josso N. Testicular dysgenesis does not affect expression of anti-Müllerian hormone by Sertoli cells in premeiotic seminiferous tubules. American Journal of Pathology 1996148 1689-1698.

38 Young J, Rey R, Schaison G \& Chanson P. Hypogonadotropic hypogonadism as a model of post-natal testicular anti-Müllerian hormone secretion in humans. Molecular and Cellular Endocrinology 2003211 51-54. (doi:10.1016/j.mce.2003.09.020)

39 Rey RA, Venara M, Coutant R, Trabut JB, Rouleau S, Lahlou N, Sultan C, Limal JM, Picard JY \& Lumbroso S. Unexpected mosaicism of R201HGNAS1 mutant-bearing cells in the testes underlie macro-orchidism without sexual precocity in McCune-Albright syndrome. Human Molecular Genetics 200615 3538-3543. (doi:10.1093/hmg/ddl430)

40 Venara M, Rey R, Bergadá I, Mendilaharzu H, Campo SM \& Chemes H. Sertoli cell proliferations of the infantile testis: an intratubular form of Sertoli cell tumor? American Journal of Surgical Pathology 200125 1237-1244. (doi:10.1097/00000478-200110000-00003)

41 Sakamoto H, Saito K, Oohta M, Inoue K, Ogawa Y \& Yoshida H. Testicular volume measurement: comparison of ultrasonography, orchidometry, and water displacement. Urology 200769 152-157. (doi:10.1016/j.urology.2006.09.012)

Received 18 September 2015

Revised version received 23 November 2015

Accepted 15 December 2015 